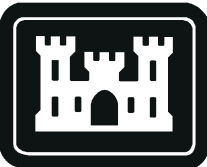

US Army Corps

of Engineers

Waterways Experiment

Station

Water Quality Research Program

\title{
Review of Watershed Water Quality Models
}

by Patrick N. Deliman, Roger H. Glick, Carlos E. Ruiz

Approved For Public Release; Distribution Is Unlimited
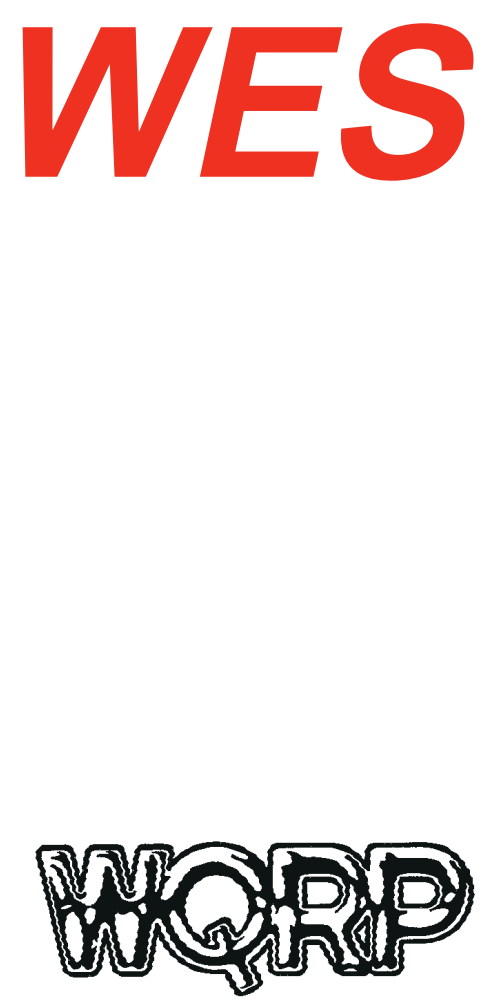
The contents of this report are not to be used for advertising, publication, or promotional purposes. Citation of trade names does not constitute an official endorsement or approval of the use of such commercial products.

The findings of this report are not to be construed as an official Department of the Army position, unless so designated by other authorized documents. 


\section{Review of Watershed Water Quality Models}

by Patrick N. Deliman, Carlos E. Ruiz

U.S. Army Corps of Engineers

Waterways Experiment Station

3909 Halls Ferry Road

Vicksburg, MS 39180-6199

Roger H. Glick

Texas A\&M University

201 Scoates Hall

Department of Agricultural Engineering

College Station, TX 77843

Final report

Approved for public release; distribution is unlimited

Prepared for U.S. Army Corps of Engineers

Washington, DC 20314-1000 


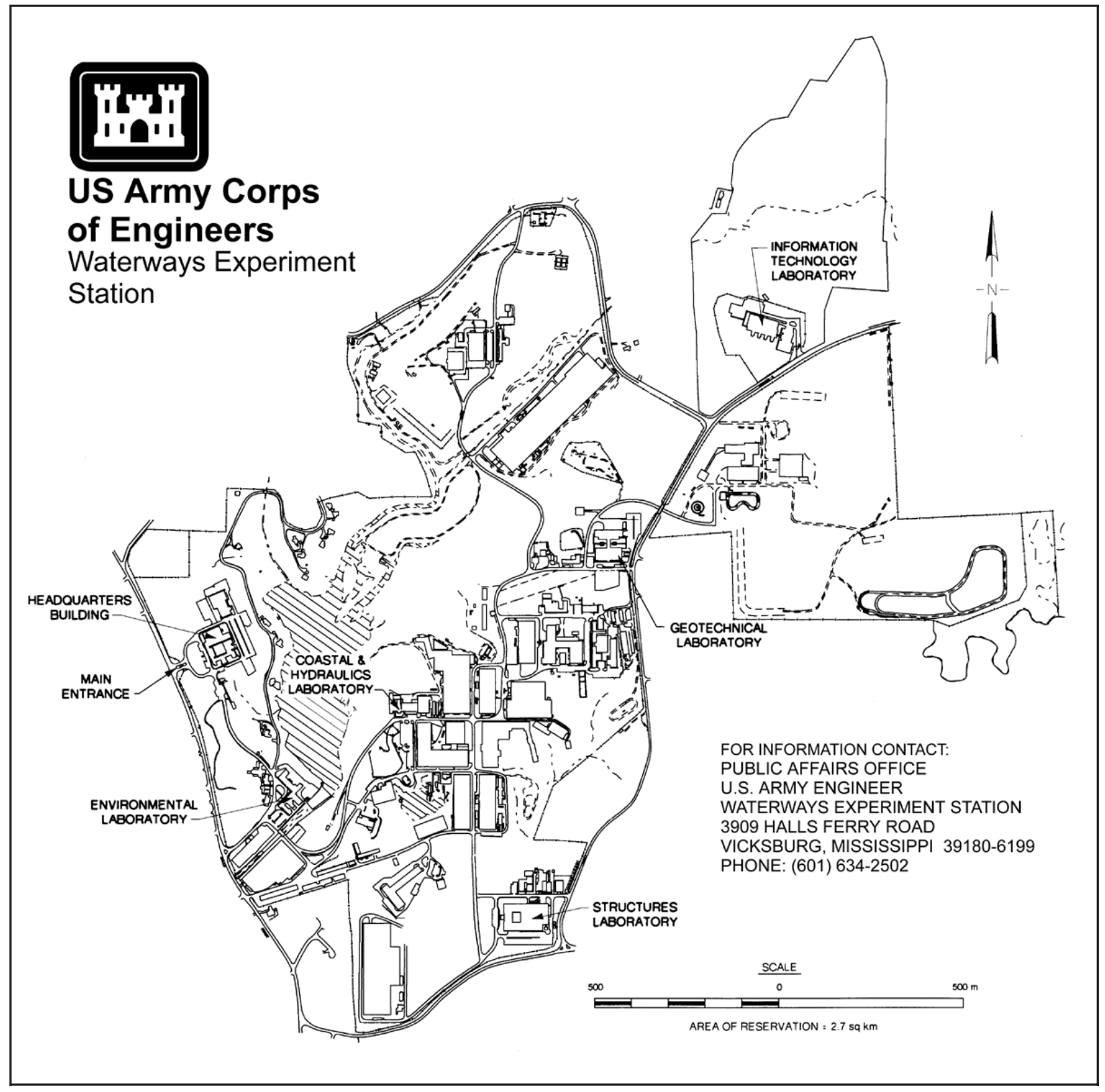

\section{Waterways Experiment Station Cataloging-in-Publication Data}

\section{Deliman, Patrick N.}

Review of watershed water quality models / by Patrick N. Deliman, Roger H. Glick, Carlos E. Ruiz ; prepared for U.S. Army Corps of Engineers.

31 p. : ill. ; $28 \mathrm{~cm}$. - (Technical report ; W-99-1)

Includes bibliographic references.

1. Watershed management - Mathematical models - Computer programs. 2. Water quality Mathematical models - Computer programs. I. Glick, Roger Holden, 1965- II. Ruiz, Carlos E. III. United States. Army. Corps of Engineers. IV. U.S. Army Engineer Waterways Experiment Station. V. Water Quality Research Program (U.S.) VI. Title. VII. Series: Technical report (U.S. Army Engineer Waterways Experiment Station) ; W-99-1.

TA7 W34 no.W-99-1 


\section{Contents}

Preface ........................ iv

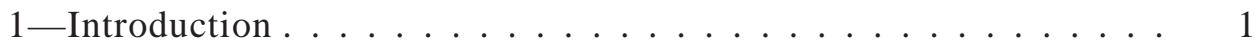

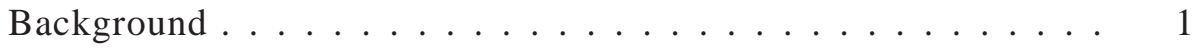

Water Quality Models .................. 2

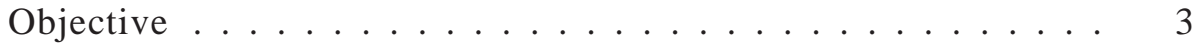

2-Model Review ..................... 4

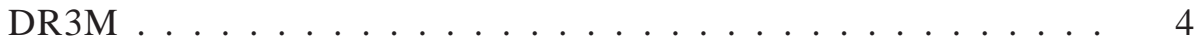

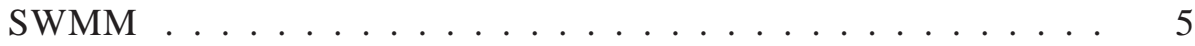

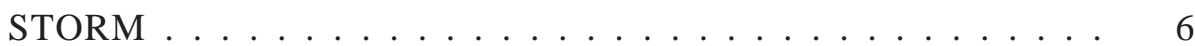

CREAMS/GLEAMS . . . . . . . . . . . . . . 7

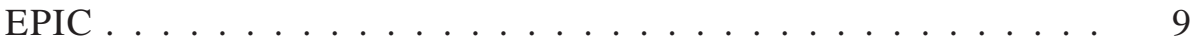

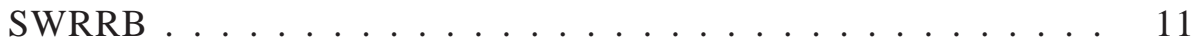

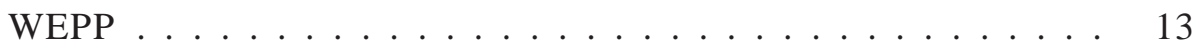

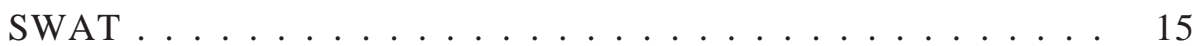

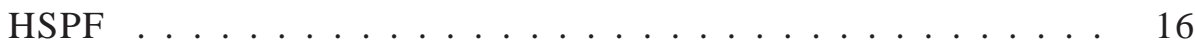

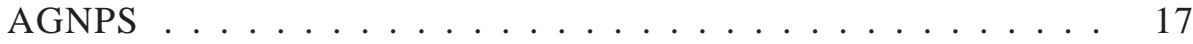

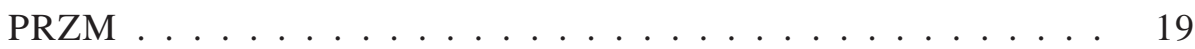

3-Conclusions and Model Recommendations . . . . . . . . . . 21

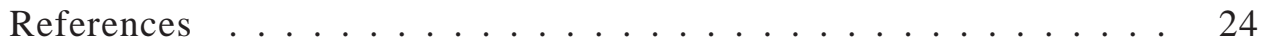

SF 298 


\section{Preface}

The work reported herein was conducted as part of the Water Quality Research Program (WQRP), Work Unit 32989. The WQRP is sponsored by the Headquarters, U.S. Army Corps of Engineers (HQUSACE), and is assigned to the U.S. Army Engineer Waterways Experiment Station (WES) under the purview of the Environmental Laboratory (EL). Funding was provided under Department of the Army Appropriation No. 96X3121, General Investigation. Dr. John W. Barko was Program Manager for the WQRP. Mr. Robert C. Gunkel, Jr., was Assistant Manager for the WQRP. Program Monitors during this study were Mr. Frederick B. Juhle, Ms. Cheryl Smith, and Mr. Lewis Smith, HQUSACE.

This report was prepared by Drs. Patrick N. Deliman and Carlos E. Ruiz, Water Quality and Contaminant Modeling Branch (WQCMB), Environmental Processes and Effects Division (EPED), EL, WES, and Dr. Roger H. Glick, Research Associate, Texas A\&M University, College Station, Texas. Ms. Lillian Schneider and Dr. Carl F. Cerco, WQCMB, were technical reviewers for this report.

The work was conducted under the general supervision of Dr. Mark S. Dortch, Chief, WQCMB, Dr. Richard E. Price, Chief, EPED, and Dr. John Harrison, Director, EL.

At the time of the publication of this report, Commander of WES was COL Robin R. Cababa, EN.

This report should be cited as follows:

Deliman, P. N., Glick, R. H., and Ruiz, C. E. (1999).

"Review of Watershed Water Quality Models," Technical Report W-99-1, U.S. Army Engineer Waterways Experiment Station, Vicksburg, MS.

The contents of this report are not to be used for advertising, publication, or promotional purposes. Citation of trade names does not constitute an official endorsement or approval of the use of such commercial products. 


\section{Introduction}

\section{Background}

Increasing computer speed and the development of new mathematical representations of physical processes have outdated many water quality models. Several models used in the past to simulate nonpoint source (NPS) pollution are adequate, but many areas need to be upgraded to take advantage of recent developments in modeling and computer speed.

Models are used to help in long-term planning to determine the best methods to reduce NPS pollution and maintain water quality. Reduction of NPS pollution is accomplished by using best management practices (BMP's). Accurate modeling is essential in determining how various BMP's will impact water quality, alone or in conjunction with others. The purpose of this report is to compare and evaluate existing hydrologic and watershed water quality models. Recommendations for a base model(s) to be used to predict NPS pollution will be made. Areas for model improvement will be identified to increase the model's reliability and usability. Viable modeling approaches today typically are comprehensive. These models contain components to account for both NPS and point source pollutants.

Since NPS pollution is most often associated with runoff events, the hydrologic portion of each model will be examined first. Many early models used empirical relationships to determine runoff and peak flow, such as the Soil Conservation Service (SCS) curve number, rational method, SCS TR-55. Increases in computational speed have allowed many models to be developed that represent each process of the hydrologic cycle individually with a model based on the physics of the process. The differing manners in which the models simulate infiltration, evapotranspiration, percolation, and runoff routing will be examined. The applicability of the model in both urban and rural settings will be addressed.

Initially, sediment was the only component of NPS pollution studied. Many models use the Universal Soil Loss Equation (USLE) or some modification to predict sediment loading. The state of the art now includes modeling the processes of detachment, deposition, and transport rather than 
using the regression approach of the USLE. This allows the user to examine the temporal as well as spatial changes in sediment loading. Increasing concerns of pesticides, nutrients, and other chemicals entering the water system have caused their inclusion in many watershed models. When these other pollutants are considered, adsorption, degradation, and solubility must also be considered. The other pollutants should be accounted for from the time they enter the watershed until they leave or are degraded, including in channels and impoundments. The effects of these pollutants on groundwater should also be taken into account.

Two items affect model accuracy more than any others, scale and time step. When models are applied over too large an area, many parameters are lumped or averaged for the area. This neglects the small-scale heterogeneities that are found in the real world and affect runoff quality and quantity. If the time step is too long, many physically based models do not operate properly, and the benefits of using distributed rather than lumped parameters are lost. The ideal solution would be to use a distributed parameter model with a short time step, but this introduces two more concerns, data collection and computational time. Collection of the necessary meteorologic data and watershed parameters for a long-term simulation of a large watershed could be burdensome and quite voluminous. To help alleviate this burden, linking the model with a geographic information system (GIS) and using weather simulators is desirable. To reduce computational time, changes in the time step may be used during times with no rainfall to increase the efficiency of the model.

\section{Water Quality Models}

Models vary in many ways: time step, scale, whether the model simulates single events or on a continuous basis, and how different components are computed. For NPS modeling, the only feasible option is to incorporate a continuous approach. Loadings from a watershed area need to be represented over time, not just for a single event. The first area that will be examined in this model review is how runoff is computed. One common method to compute the amount of runoff from daily rainfall data is to use the SCS curve number method. This empirical method is based on numerous tests relating soil moisture, soil type, and land use to the depth of runoff from a given depth of rainfall. Other methods require the modeling of rainfall abstractions, such as interception, infiltration, and evaporation, to determine the amount of runoff. Various methods of differing complexity can be used to compute the abstraction. Some models keep track of water once it has percolated into the soil to examine interflow and groundwater recharge. Groundwater percolation is a necessary component for most reasonably sized watersheds.

Once the amount of runoff has been computed, routing of the runoff to a receiving body becomes the focus. Some models offer accurate but complex methods of solving the continuity and conservation of momentum 
equations. These models incorporate either modified forms of St. Venant's equation or an approach known as the kinematic wave approximation.

These methods require a shorter time step than is practical for some models. Use of synthetic hydrographs based on storm duration and amount of runoff may be used. Several methods have been developed by the SCS to determine peak runoff rate (TR-20, TR-55, and rational method). Many routing methods are currently available including those which are fully hydrodynamic. After the runoff has reached a channel or reservoir, it must be routed to the outlet of the watershed. Many routing methods are available, including those that are fully hydrodynamic.

Sediment yield can be computed in several ways. Most models use a variation of the USLE. The original USLE was developed to predict longterm soil loss, but modifications allow its use for individual storms. The main variation between models is whether rainfall, runoff, or a combination provide the energy for erosion. In urban models simple build-up/ wash-off relationships are utilized to approximate erosion. More detailed models compute detachment based on both rainfall and runoff energy and then compute transport capacity based on runoff to determine sediment yield. Models may compute sediment deposition and erosion in channels and ponds.

If chemical transport is considered, several items need to be reviewed. For nutrients, nitrogen and phosphorus, the biochemical processes that affect the form of the nutrient need to be taken into account. For pesticides, decay should be included as well as simulation of decay components. Dividing the chemical transport between adsorbed and soluble portion must be considered. Chemical effects on groundwater may be included. Biochemical processes need to be simulated during all phases of transport, not just on the field. Crop growth and time of year (impacts through other time-dependent processes) will affect chemical transport; therefore, their impacts need to be simulated as well.

\section{Objective}

The objective of this study is to review existing watershed water quality models and select a building block for the development of a Corps of Engineers modeling capability for predicting watershed runoff water quality as influenced by land use change, development, watershed improvement strategies, and BMP's. Other factors will be examined during the review of existing models. The methods used to assign various parameters to different locations in the watershed will be examined. Input requirements and possible simulation of inputs will also be reviewed. 


\section{Model Review}

The following is a brief overview of some of the existing watershed water quality models that are readily available. The review is in no way all inclusive but represents models that are commonly used and well validated. The water quality models may be broken into two groups, urban and nonurban. The urban models are STORM, SWMM, and DR3MQUAL. Nonurban models include CREAMS/GLEAMS, EPIC, SWRRB, PRZM, AGNPS, HSPF, WEPP, and SWAT. Several of these models have been applied in both settings, but are categorized based on their initial development.

\section{DR3M}

The Distributed Routing, Rainfall, Runoff Model (DR3M) was developed by the U.S. Geological Survey (USGS) to simulate urban runoff at various points in the watershed. The hydrographs generated by DR3M are used by a companion model, DR3M-QUAL, to simulate runoff quality (Alley and Smith 1982b).

\section{Hydrology}

DR3M (Alley and Smith 1982a) breaks runoff into four types of segments: overland, channel, reservoir, and nodal. Each segment computes runoff differently. Runoff from overland segments is computed using the kinematic wave approximation. A daily soil moisture balance is maintained using pan evaporation. Infiltration is approximated using GreenAmpt methodology to compute rainfall excess. Two types of overland segments are considered, pervious and impervious. A portion of the rainfall may be stored in impervious areas but does not infiltrate. The time step and distance used in the kinematic wave approximation are set by the user. Routing in the channel segments is also done using kinematic wave. The user must specify the channel shape and size. Flow into a pipe may be simulated by specifying a circular channel shape. Reservoir routing can be simulated by linear storage or modified pulse routing. Nodal segments are those where three or more of the other segments meet. Flow out of the 
nodal segment is computed as the sum of the segments entering the nodal segment. Nodal segments may also be used to input a hydrograph or remove runoff.

\section{Sediment and other pollutants}

The production of sediment is computed in DR3M-QUAL (Alley and Smith 1982b) as a function of time between storms, build up/wash off, for the impervious areas. Sediment from the pervious areas is computed using a regression relationship developed from the USLE. Other constituents may be simulated as a fraction of the sediment. Soluble contaminants are not modeled. Pollutants in the channels are assumed not to mix, and the transport is simulated using Lagrangian methods. It is assumed reservoirs are plug flow and do not mix. Settling is allowed in reservoirs following Stokes' Law.

\section{Model use}

DR3M-QUAL is not presently available in PC form. ${ }^{1}$ DR3M is PC compatible, and the source code for the quality portion of the model is accessible. DR3M has received extensive use and review by USGS. DR3M-QUAL has been used in-house by USGS to a lesser extent.

\section{SWMM}

The Storm Water Management Model (SWMM) was developed in 1969-71 for the Environmental Protection Agency (EPA) by Metcalf and Eddy, Inc., in conjunction with University of Florida and Water Resources Engineers, Inc. SWMM has been updated several time over the years with version 4.30 being released in May 1994 (Center for Exposure Assessment Modeling (CEAM) 1994). SWMM is one of the most widely used urban water quality models (Wurbs 1995).

\section{Hydrology}

Runoff and routing in SWMM are more hydraulic than hydrologic (Viessman et al. 1977). Runoff from small subcatchments (single parking lots, city lots, etc.) is first routed overland to gutters or storm drains using Manning's equation and continuity. Infiltration is computed using Horton's equation or Green-Ampt methodology. Depression storage fills before overland flow begins. Evapotranspiration is neglected. Once the overland flow enters a gutter or drain, the flow is combined with upstream

1 Personal Communication, 1995, Kate Flynn, USGS, Reston, VA. 
flow and routed to the final outflow. The Extran Block in SWMM solves the complete dynamic flow routing equations (St. Venant's equation) to accurately simulate backwater, looped connections, surcharging, and pressure flow (CEAM 1994). SWMM may easily be calibrated using measured hydrographs at any point in the flow system.

\section{Sediment and other pollutants}

Several methods are available to simulate water quality. Sediment production from pervious areas is accomplished using USLE. In impervious areas, build-up/wash-off methods, rating curves, or constant concentration can be used. SWMM also simulates deposition and scour in sewers. Firstorder decay of constituents may be simulated (CEAM 1994).

\section{Model use}

SWMM is widely used for urban storm water planning and has been thoroughly validated. For this purpose, SWMM is an excellent model; however, it cannot be applied readily to rural watersheds (Viessman et al. 1977). SWMM has been continually updated and is supported by EPA's CEAM. A commercial PC version, XP-SWMM, is available with better data input interfaces.

\section{STORM}

In the early 1970's the Hydrologic Engineering Center (HEC) developed the Storage, Treatment, Overflow Runoff Model (STORM) for use in urban areas. The output from STORM is divided into statistics on runoff quality and quantity and pollutographs for individual events. The main use of STORM has been for sizing control structures (HEC 1977). Use of STORM has decreased in recent years, and HEC no longer supports the model; however, several private firms have updated STORM and support it as ProSTORM. ${ }^{1}$

\section{Hydrology}

STORM (HEC 1977) has three methods to compute surface runoff, the SCS curve number method, a runoff coefficient method, or a combination method where curve numbers are used on pervious areas and coefficients are used on impervious areas. Evaporation and rainfall are user inputs. STORM computes soil moisture conditions from evaporation data to select the proper curve number. Dry weather flows are provided by the

1 Personal Communication, 1995, Arlen Feldman, HEC, Davis, CA. 
user to simulate combined sewers. Flow is routed using a unit hydrograph method. Storage, treatment, and overflow are computed hourly during rainfall events, but not during dry periods.

\section{Sediment and other pollutants}

Sediment production from pervious areas is computed using the USLE. Sediment production from other areas is based on daily build-up/wash-off relationships. Nitrogen, phosphorus, biochemical oxygen demand (BOD), and coliforms may also be simulated, but they are only represented by loading functions and do not degrade or cycle (HEC 1977).

\section{Model use}

STORM was applied in several runoff studies in the late 1970's and early 1980's (Donigian and Huber 1990). Abbott (1978) compared STORM to other continuous and event models as well as actual data and achieved good results. HEC no longer supports STORM, and a PC version is currently available. ProSTORM is available for PC use from private consulting firms. ${ }^{1}$

\section{CREAMS/GLEAMS}

The Chemical, Runoff, and Erosion from Agricultural Management Systems (CREAMS) model was the first in a series of models developed by the U.S. Department of Agriculture (USDA). The original model focused on surface water quality, but groundwater quality was added to form the Groundwater Loading Effects of Agricultural Management Systems (GLEAMS) model (Knisel 1993). GLEAMS has replaced CREAMS for the most part, but CREAMS is the recognized predecessor for several other models. CREAMS is a field-scale model used to look at edge of field loading sediment, nutrients, and pesticides with various management practices. With the additions in GLEAMS, leaching below the root zone may also be examined (Knisel 1993). CREAMS/GLEAMS is one of the most detailed field-scale models currently in use. USDA's Agriculture Research Service (USDA-ARS) has recently developed the Soil and Water Assessment Tool (SWAT) by extending GLEAMS to basin scale.

1 Personal Communication, 1995, Arlen Feldman, HEC, Davis, CA. 


\section{Hydrology}

The hydrology component of the model is based on a daily water balance. Surface runoff is based on the SCS curve number method when daily rainfall data are used. If breakpoint rainfall data are used, runoff is computed using Green-Ampt infiltration and kinematic wave routing. The peak runoff rate is estimated by regression relationships (Smith and Williams 1980). Percolation is computed using a storage-routing technique to predict flow through each soil layer. Lateral subsurface flow is computed for each soil layer using a kinematic storage model starting at the top layer and progressing downward (Knisel 1993). Soil evaporation may be computed using the Priestly-Taylor method or Penman-Monteith. Plant evapotranspiration is based on the Ritchie method and requires the leaf area index depending on the stage of crop growth. Snowmelt and transmission losses are also taken into account (Knisel 1993). The CREAMS/ GLEAMS models have no channel routing since they are field-scale models.

\section{Sediment and other pollutants}

Sediment yield in CREAMS is computed using detachment, deposition, and transport equations. Detachment is divided into two categories, rill and interrill. Detachment in the interrill areas is based on rainfall energy, and rill erosion is based on flow velocities. The interrill erosion is computed first; then the transport capacity is computed. If the transport capacity of the overland flow exceeds the interrill sediment load, rill erosion is computed. The sediment load is the lesser of transport capacity and the combined rill-interrill sediment load. If the interrill sediment load exceeds transport capacity, deposition occurs. Five particle sizes are considered for sediment transport and detachment/deposition: sand, silt, clay, small aggregates, and large aggregates. Deposition in small impoundments and transport and deposition in terraces or small channels is also considered (Foster et al. 1980).

CREAMS/GLEAMS has a well-documented submodel for dealing with pesticides that can handle up to 20 pesticides at once (Knisel 1993). The amount of pesticide lost to runoff is computed as a soluble fraction and an adsorbed fraction of the available pesticide that has not leached, volatilized, decayed, or otherwise been lost. Different methods of pesticide application, foliar or soil incorporated, are considered, and the effects on the initial concentrations of pesticides are computed. Using GLEAMS, the amount of pesticide that leaches to the groundwater may also be determined (Knisel 1993). Since the model only looks at edge of field concentration, no degradation is considered in the channels.

Nitrogen losses are considered for both nitrate and organic nitrogen. For nitrate, the daily soil nitrate content is computed for each soil layer. The amount of nitrate that is leached from each layer is computed and will percolate to the groundwater or may reappear with return flow. 
Nitrate in the runoff is computed using the nitrate in the top soil layer only. Organic nitrogen is considered with the sediment with a loading function. Crop uptake of nitrogen is also considered. The different processes that affect nitrogen are considered, mineralization, immobilization, denitrification, volatilization, and fixation (Knisel 1993). Phosphorus is mainly transported with sediment such as organic nitrogen. Soluble phosphorus transported by runoff is computed from the level of phosphorus in the top soil layer. Application of fertilizers and crop growth and residue are taken into account when computing the nutrient levels in each soil layer (Knisel 1993).

\section{Model use}

The CREAMS/GLEAMS models have been widely used in many areas (Knisel 1993). Long-term studies on well-instrumented fields have shown that the methodologies used in CREAMS/GLEAMS work well. The models are readily available for PC use.

\section{EPIC}

Concerns over the possible decrease in agricultural productivity due to soil loss prompted the creation of the Erosion/Productivity Impact Calculator (EPIC) model. EPIC was developed to determine the long-term productivity of soil using various management strategies (Williams 1994 and Dumesnil 1993). Simulations using EPIC are usually done on small areas over a long period of time. Since the model's main purpose is to compute productivity, a greater portion of the model deals with crop growth compared with other models, but water yield, sediment production, and nutrient removal are also considered (Williams 1994).

\section{Hydrology}

The hydrology component of the model is based on a daily water balance. Surface runoff is based on the SCS curve number method, and the peak runoff rate is estimated by the rational formula. Percolation is computed using a storage-routing technique to predict flow through each soil layer. Once water has percolated past the root zone, it is considered groundwater and lost from the model. Lateral subsurface flow is computed for each soil layer using a kinematic storage model starting at the top layer and progressing downward. Soil evaporation may be computed using either the Penman-Monteith method or the Priestly-Taylor method. Plant evapotranspiration is based on the Ritchie method and requires the leaf area index depending on the stage of crop growth. Snowmelt and transmission losses are also taken into account. Since EPIC is a smallscale model, channel routing is not considered. Irrigation of crops may be 
considered with the daily water balance (Williams 1994 and Sharpley and Williams 1990).

\section{Sediment and other pollutants}

Sediment yield may be computed in one of three ways specified by the user, USLE, Modified USLE (MUSLE), or the Onstad-Foster modification of the USLE. Erosion from furrow irrigation is always computed using MUSLE. The variation between these models is the energy factor used to drive erosion; USLE uses rainfall only, MUSLE uses runoff only, and Onstad-Foster uses a combination of rainfall and runoff. As sediment leaves the field, the surface layer of soil is reduced in thickness until it no longer remains. Erosion continues to move through the soil profile, allowing for soil weathering (Williams 1994 and Sharpley and Williams, 1990). Wind erosion is computed, but washoff does not affect runoff sediment loads (Sharpley and Williams 1990).

Losses of nitrate are considered from the top layer of soil only. Nitrate that is adsorbed and in solution may leave with the runoff. Nitrate in solution may also leave the field though percolation or lateral subsurface flow.

Loading functions for organic nitrogen are also provided. Nitrogen may be moved into the top soil layer as water in that layer evaporates and water from lower layers enters. The nitrogen cycle is simulated by the processes of denitrification, mineralization, immobilization, and fixation. The concentration of nitrogen in rainfall may also be included. Phosphorus is transported in solution or with sediment. The phosphorus cycle includes mineralization, immobilization, and mineral cycling. EPIC does not track pesticide losses (Williams 1994, and Sharpley and Williams 1990).

\section{Other features}

EPIC is able to generate long-term sediment predictions because of its built-in weather generator and weather database (Sharpley and Williams 1990). Rainfall timing is based on the probability of a wet day following a dry day and a wet day following a wet day. Daily rainfall amounts are predicted using a skewed normal distribution with the mean rainfall and standard deviation for the month. Air temperature and solar radiation are correlated with rainfall. Wind speed is predicted from a two-parameter gamma distribution, and direction is based on a cumulative probability distribution. Daily relative humidity is derived using the monthly average and a triangular distribution and adjusting for a wet or dry day. Soil temperature and soil $\mathrm{pH}$ are also computed and applied to the nutrient cycle. 
EPIC includes a crop growth simulator to account for various stages of crop growth and their impacts such as nutrient uptake, transpiration, and soil residue. An economic section is included to further assess soil productivity (Williams 1994, and Sharpley and Williams 1990).

\section{Model use}

EPIC has been used to simulate many different things, soil productivity, crop growth, and soil degradation (Dumesnil 1993). Sharpley and Williams (1990) report on the validation of the model components and application of the complete model to differing soils and climates. Sensitivity analysis was also reported. EPIC is available for PC use and is well documented and supported by USDA-ARS.

\section{SWRRB}

The SWRRB (Simulator for Water Resources in Rural Basins) model was developed by the USDA-ARS to determine the effects of management practices on water and sediment yields in small ungaged rural basins (Arnold and Williams 1994). The model was developed by the USDA extending the CREAMS/GLEAMS methodology from field scale to basin scale. The major processes included in the model are surface runoff, percolation, return flow, transmission losses, pond and reservoir storage, sedimentation, pesticide fate, nutrient cycling, and crop growth. Several subbasins with varying soil, crop, and weather conditions can be simulated as part of a single watershed. The model was designed to look at long-term effects of management strategies, but single runoff events can be simulated.

\section{Hydrology}

The hydrology component of the model is based on a daily water balance. Surface runoff is based on the SCS curve number method, and the peak runoff rate can be estimated by either the rational formula or SCS TR-55 method. Percolation is computed using a storage-routing technique with a crack flow model to predict flow through each soil layer. Once water has percolated past the root zone, it is considered groundwater, but may appear as return flow in downstream basins. Lateral subsurface flow is computed for each soil layer using a kinematic storage model starting at the top layer and progressing downward. Soil evaporation may be computed using either the Hargreaves-Samani method or the Priestly-Taylor method. Plant evapotranspiration is based on the Ritchie method and requires the leaf area index depending on the stage of crop growth. Snowmelt and transmission losses are also taken into account (Arnold and Williams 1994). Since SWRRB is a long-term water and sediment yield predictor, flood routing is not performed. Daily basin outflow is computed 
by summing the subbasin outflow. Farm ponds and reservoirs can be simulated with SWRRB. Irrigation of crops may be considered with the daily water balance (Arnold and Williams 1994).

\section{Sediment and other pollutants}

Sediment yield is computed for each subbasin using MUSLE. Sediment in channel routing consists of two processes operating simultaneously, deposition and degradation. Stokes' Law is applied to each sediment size for each channel reach to determine deposition. Channel degradation is a function of the stream power. Sediment is allowed to be deposited and reentrained in the channel before reaching the basin outlet. A sediment balance is maintained for ponds and reservoirs as well (Arnold and Williams 1994).

SWRRB uses the same methodology as GLEAMS (Knisel 1993) to deal with pesticides. First the amount of pesticide reaching the ground is computed dependent on the stage of crop growth. The amount of pesticide that leaches to the groundwater is computed. The amount of pesticide lost to runoff is computed as a soluble fraction and an adsorbed fraction of the available pesticide that has not leached, volatilized, decayed, or otherwise been lost. Pesticides that are adsorbed to sediment are allowed to be deposited in the channel. Soluble pesticides are considered conservative in the channel and do not degrade (Arnold and Williams 1994).

Nitrogen losses are considered for both nitrate and organic nitrogen. For nitrate, the daily soil nitrate content is computed for each soil layer. The amount of nitrate that is leached from each layer is computed and will percolate to the groundwater or may reappear with return flow. Nitrate in the runoff is computed using the nitrate in the top soil layer only. Organic nitrogen is considered with the sediment with a loading function. Crop uptake of nitrogen is also considered. Phosphorus is mainly transported with sediment such as organic nitrogen. Soluble phosphorus transported by runoff is computed from the level of phosphorus in the top soil layer, but leaching is not considered. Soluble nutrients are considered conservative in the basin channels, but adsorbed nutrients may be deposited or entrained in the channel. Application of fertilizers and crop growth and residue are taken into account when computing the nutrient levels in each soil layer (Arnold and Williams 1994).

\section{Other features}

SWRRB allows the user to input the required weather data (daily rainfall and temperature), or a stochastic weather generator can simulate the weather. Solar radiation is always simulated. The probability of a rainfall event is simulated using a first-order Markov chain. When rainfall does occur, the amount is simulated from a skewed normal distribution. Temperature and solar radiation are simulated using Richardson's model 
which correlates temperature and radiation with precipitation. Weather may be simulated for the entire basin or each subbasin individually. The parameters needed for the weather generator are included with the model for locations across the United States including Puerto Rico (Arnold and Williams 1994).

Tillage practices, crop residue, and crop growth are simulated as well as how they affect soil properties. Data for numerous soils that may be used are included with the model or may be input by the user for each subbasin. A utility program is included to assist with data entry, but the input is still in tabular form. The output is in tabular form. SWRRB has been combined successfully with a lake water quality model to simulate the end effects of management decisions (Arnold and Williams 1994).

\section{Model use}

SWRRB has been used and validated in a variety of settings. The model has been used to predict urbanization, coastal pollution, pesticide assessment, pond irrigation, and water rights (Arnold and Williams 1994). Support and documentation for the PC version of SWRRB are available from USDA-ARS.

\section{WEPP}

The objective of the Water Erosion Prediction Project (WEPP) is to develop a new-generation, process-oriented model to predict soil erosion. The WEPP model represents the start of a new generation of USDA models. It was developed for continuous simulations of small watersheds, less than 260 ha, or individual hillslopes. WEPP allows the user to look at spatial and temporal variations in sediment production. While this newly developed model uses some of the most up-to-date methodology, since some components are missing it is not a complete water quality model (Flanagan et al. 1995).

\section{Hydrology}

The hydrology of WEPP is more complex and physically based than SWRRB. The hydrology component of the model is based on a daily water balance. Surface runoff is computed as the rainfall excess, rainfall less infiltration, rather than using an empirical method. Infiltration is computed using the Green-Ampt equation as modified by Mein and Larson. Peak runoff and runoff rate are computed by routing the rainfall excess downslope using the kinematic wave approximation. Percolation is computed using methods similar to SWRRB as well as simulating flow to drain tiles and ditches. WEPP computes soil evaporation using either the Penman method or the Priestly-Taylor method. Plant evapotranspiration is 
based on the Ritchie method and requires the leaf area index depending on the stage of crop growth (Stone et al. 1995). Snowmelt and transmission losses are also taken into account (Savabi et al. 1995). In the watershed mode, WEPP routes hillslope runoff through channels to compute the basin outflow. Farm ponds and reservoirs can be simulated as with SWRRB (Ascough et al. 1995). Irrigation of crop may be considered with the daily water balance.

\section{Sediment and other pollutants}

WEPP computes sediment yield in a method similar to CREAMS/ GLEAMS. Sediment production is divided into two parts, rill and interrill. Detachment in the interrill areas is a function of rainfall intensity, and the detachment process is dominated by raindrop impact. All interrill sediment is carried to the rills or small channels. The transport capacity of the rill is then computed, and interrill sediment is either deposited or transported. If the rill has an excess transport capacity, detachment of sediment in the rill is assumed to occur. Various soil particle sizes are considered (Foster et al. 1995). Unlike CREAMS/GLEAMS, transport capacity and shear stress is based on rill hydraulics rather than sheet flow. Sediment is allowed to be deposited and detached in the channel when using the watershed version of WEPP (Ascough et al. 1995). Unlike the other model, WEPP does not rely on the USLE to incorporate management factors, but rather focuses on the physical processes.

\section{Other features}

WEPP uses the weather generator developed for EPIC and SWRRB with some additions and refinements (Nicks, Lane, and Gander 1995). The probability of a rainfall event is simulated using a first-order Markov chain. When rainfall does occur, the amount is simulated from a skewed normal distribution. Because WEPP does not use the SCS method to compute runoff, storm duration, peak intensity, and break point rainfall are computed. Temperature and solar radiation are simulated using Richardson's model which correlates temperature and radiation with precipitation. Dew point, wind speed, and direction are additions for use by the evapotranspiration computations. Weather may be simulated for the entire basin or each hillslope individually. The weather files included with WEPP are not as extensive as SWRRB at this time. Linking WEPP with GIS and the National Climatic Data Center is currently being explored (Flanagan et al. 1995).

Tillage practices, crop residue, and crop growth are simulated as well as how they affect soil properties. Data for several soils that may be used are included with the model or may be input by the user for each subbasin. The user can use several previously developed files to create a watershed by combining soils, weather, conservation practices, slope, and channel files. 


\section{Model use}

Many of the components of WEPP have been validated separately, but no widespread use of WEPP has been reported. The model is still under development and has yet to be fully verified and validated. Components of WEPP may be used in other models. PC versions of the model, as well as documentation, support, and development, are available from the USDA-ARS National Soil Erosion Laboratory.

\section{SWAT}

The Soil and Water Assessment Tool (SWAT) model is the latest model developed by the USDA-ARS. Where SWRRB was an extension of CREAMS/GLEAMS from field scale to small watershed scale, SWAT is the extension of SWRRB to basin scale (Arnold et al. 1995). SWAT was developed by including ROTO (Routing Output to Outlets) with SWRBB. Complete flow and contaminant routing is accomplished as well as the inclusion of GIS interfaces, a weather generator, lake water quality, and water management options.

\section{Hydrology}

Runoff is estimated using daily rainfall data using the SCS curve number method with peak runoff computed using a modification of the rational method. Time to concentration for both channels and overland flow is estimated using Manning's equation. Percolation and lateral subsurface flow are computed together and are based on storage routing and kinematic routing. Groundwater flow is simulated based on a shallow aquifer model with evaporation, pumping, seepage, and discharge being included. The daily water balance includes evapotranspiration based on Hargreaves-Samani, Priestly-Taylor, or Penman-Monteith equations. Plant transpiration is based on the Ritchie method. Transmission losses in channels are considered along with ponds and other small structures that will reduce runoff quantity (Arnold et al. 1995). Water may be transferred from one portion of the watershed to another to simulate pumping and irrigation.

\section{Sediment and other pollutants}

Sediment yield is based on the MUSLE. Nitrogen, phosphorus, and pesticides are simulated using the CREAMS/GLEAMS (Knisel 1993) models including biochemical processes and groundwater loading as described earlier in this report. During runoff events, chemical degradation is not simulated in the channels, but a lake water quality model has been added to simulate lake processes. Sediment-bound chemicals may settle and be detached in channels. Crop growth simulators are included to account for 
changing ground cover and plant uptake of nutrients. Point sources may also be included in the simulations (Arnold et al. 1995).

\section{Other features}

SWAT includes a weather generator similar to the one used in EPIC, SWRRB, and WEPP for long-term simulations and numerous weather station locations to reduce user input (Arnold et al. 1995). Weather may be simulated for the entire basin or for each subwatershed individually as is done in SWRRB (Arnold and Williams 1994). SWAT also includes an interface with GRASS (Geographic Resources Analysis Support System) GIS (Arnold et al. 1995). This allows the user to easily input data from a large heterogeneous basin. One feature in SWAT not seen in any other model is the mixing of watershed delineation techniques. A grid system, as seen in AGNPS (Agricultural Non-Point Source pollution model), may be used in areas of special interest while the rest of the basin may be simulated as more homogeneous subwatersheds. This allows detailed simulation of areas of interest without a large increase in input data (Arnold et al. 1995).

\section{Model use}

SWRRB and ROTO have both been extensively tested. SWAT has been applied to several gaged watersheds and rendered good results. PC versions of SWAT along with support and documentation are available from USDA-ARS.

\section{HSPF}

The Hydrologic Simulation Program-FORTRAN (HSPF) model may be one of the most complete models to deal with urban and nonurban runoff (Donigian and Huber 1990). The hydrology of HSPF is based on the Stanford Watershed Model, developed in the early 1960's. Two erosion components deal with pervious and impervious areas separately to avoid forcing one type of model to operate in an area it was not designed to simulate. HSPF contains many submodels to simulate many of the physical, chemical, and biological processes in a watershed (Bicknell et al. 1993).

\section{Hydrology}

HSPF is based on the Stanford Watershed Model. HSPF uses basic relationships to represent the physical processes. The model, like most, is based on the water balance of the soil. Rainfall rate is a user input. Rainfall is reduced by an interception rate based on the type of ground cover. 
Evapotranspiration is based on adjusted pan evaporation data. The location that the evaporation comes from is based on the available water in certain areas. Infiltration is considered to vary linearly with time and have a maximum infiltration capacity. Interflow storage is also considered. In the impervious areas, infiltration, interflow, and soil evaporation are assumed to not occur. Overland flow is based on Darcy's law modified to adjust for the amount of surface storage during the time interval. Channel routing and reservoir storage are accomplished by using the time-area method and summing the inputs (Bicknell et al. 1993).

\section{Sediment and other pollutants}

Sediment production is based on detachment by rainfall and transport by the overland flow in a pervious area. Scouring of the soil matrix is also considered. Three sizes of sediment are considered; sand, silt, and clay are considered in streams, but not in erosion. Impervious sediment loading is determined by build-up/wash-off relationships. Sediment loading in channels and reservoirs is based on the sum of the incoming loads, and settling is allowed. Scour and deposition are based on shear stress calculations. Channels and reservoirs are considered well mixed (Bicknell et al. 1993).

Nitrogen, phosphorus, and three pesticides may be simulated. Constituents may move with sediment, on the surface in solution or in the groundwater in solution. Sorption may be simulated using first-order kinetics or Freundlich isotherms. HSPF also accounts for up to two degradation products of pesticides. Nutrient cycles and instream kinetics are simulated. Decay and instream kinetics include hydrolysis, oxidation, photolysis, volatilization, biodegradation, and generalized first-order decay (Bicknell et al. 1993). Other constituents that may be simulated include water temperature, dissolved oxygen, BOD, and algal populations (benthic, phytoplankton, and zooplankton).

\section{Model use}

HSPF has been widely used in both urban and nonurban areas and is well validated in these areas (Donigian and Huber 1990). The EPA supports HSPF, and extensive documentation is available. Short courses on the use of HSPF are regularly provided as well. PC versions of the model are available and upgrades continue. The model is supported by both EPA and USGS. 


\section{AGNPS}

Another model that was developed for agricultural watersheds is the Agricultural Non-Point Source (AGNPS) pollution model. Unlike most other models, AGNPS divides the watershed into cells based on a grid pattern. Each cell is modeled simultaneously with each other cell. The ability to set various parameters individually for each cell means better spatial description but more data input. The model was originally developed to determine the impact of feedlots on runoff quality, but it may operate with multiple point sources or as a nonpoint source model. The model will accommodate up to 28,000 cells ranging in size from 0.1 to 100 acres (0.0405 to $40.5 \mathrm{ha}$ ), but it is most commonly used for smaller watersheds (Young et al. 1994).

\section{Hydrology}

The current version of AGNPS is an event model; therefore, many of the hydrologic components normally found in other models are missing. Runoff is computed using the SCS curve number method. Peak runoff may either be computed using SCS TR-55 or the CREAMS method. The user must route the flow from cell to cell. Storm duration, intensity, and type must be entered for the entire watershed. The shape of the runoff hydrograph may also be specified by the user. Once the runoff leaves a cell it is considered to flow in channels to the outlet of the watershed. The user may specify channel shapes and flow characteristics. The user may include impoundments in the channel system, and cells may have no flow outlet to simulate features such as sink holes (Young et al. 1994).

\section{Sediment and other pollutants}

Sediment production from each cell is computed using the MUSLE. Differing slopes, slope shapes, soils, and management practices can be considered for each cell. When the sediment reaches a channel, the transport capacity of the channel is computed for differing sediment sizes to determine if there will be deposition or channel detachment. The Einstein approach is used to determine transport capacity (Young et al. 1994). Nitrogen, phosphorus, pesticide, and chemical oxygen demand concentrations my be tracked from either point or nonpoint sources. For point sources the flow rate from the cell and the pollutant concentrations must be specified. In the case of a feedlot, runoff will be computed and pollutant loads may either be specified or computed by the model based on the size and type of feedlot. Nonpoint pollution loads are calculated based on the runoff and sediment loads. Nutrients are allowed to decay in impoundments and channels. The nitrogen concentration of the rainfall may be specified by the user. Fertilizer application rates, timing, and methods may be specified. If a pesticide is simulated, its concentration in solution and in the sediment is kept in equilibrium using its partition coefficient. 
At this time only one pesticide may be simulated for each event (Young et al. 1994).

\section{Other features}

The main drawback to a grid type model like AGNPS is the large amount of data needed to simulate a large watershed. To help alleviate this drawback, AGNPS allows the use to set larger cell sizes and then subdivide the cell up to 64 times to simulate specific small features without increasing the data requirements for the entire watershed. Onscreen help is available for data entry along with a routine to check the data. Work is under way to link AGNPS with ARC-INFO and GRASS GIS databases to assist with data input and output analyses (Young et al. 1994).

\section{Model use}

AGNPS is available in a PC version and is well documented. Limited support is available through USDA-ARS (Young et al. 1994). Several studies have used AGNPS to determine pollution loading from events and assist in the reduction of runoff pollution from feedlots. The current version of AGNPS is an event model, but work is continuing on producing a continuous version. Research on AGNPS has been ongoing for numerous years.

\section{PRZM}

The Pesticide Root Zone Management (PRZM) model was developed to examine the leaching of pesticides through the root zone. PRZM has been well documented and validated for the evaluation of pesticides. The model tracks water and pesticide movement in the vertical direction only on a daily time step (Mullins et al. 1996). Recent releases of PRZM now include limited nitrogen processes.

\section{Hydrology}

Surface hydrology is greatly simplified in PRZM since it is not the main focus of the model. Runoff is computed using the SCS curve number method and rainfall that does not run off, but infiltrates. Evapotranspiration is computed from user inputs of pan evaporation or air temperature. Evapotranspiration is divided between the plants and soil to help track the pesticides. When irrigation is applied, infiltration is computed using the Green-Ampt method. Percolation is based on soil moisture retention capacities. The user may adjust the length of time it takes the soil to drain to field capacity depending on the soil texture and structure (Mullins et al. 1996). 


\section{Pesticide transport}

PRZM only computes erosion to determine the amount of adsorbed pesticide that leaves the field. Erosion is computed using the MUSLE. Pesticide movement considers volatilization from the soil as well as from the plant leaves. A balance between pesticide that is sorbed and in solution is maintained. Movement through the vadose zone is controlled by Darcy's law and Richard's equation. The transport equations can be solved by either finite difference or method of characteristics techniques. Decay and vapor phases of the pesticides are also considered (Mullins et al. 1996). PRZM includes a Monte Carlo mode that enables the user to input distributions for parameters and determine the probabilities that pesticides will leach below the root zone (Mullins et al. 1996).

\section{Model use}

PRZM has been tested and validated in several areas of the United States and is used by EPA and chemical companies to evaluate pesticide leaching (Donigian and Huber 1990). Support, documentation, and PC versions of the model are available though the EPA's CEAM (Mullins et al. 1996). 


\section{Conclusions and Model Recommendations}

Two models are the most comprehensive of those reviewed, HSPF and SWAT. The instream processes are better in HSPF, but SWAT deals more completely with field processes and groundwater. Several areas could be improved in both SWAT and HSPF. Runoff in SWAT is currently based on the SCS curve number method and the rational method to compute peak runoff rate. The use of the SCS curve number for computing water balance is unacceptable. This should be improved by simulating breakpoint rainfall and computing infiltration as in WEPP. The runoff could then be routed using kinematic wave approximations as in HSPF, WEPP, or the second option in CREAMS/GLEAMS. This could be included as a userselected option since use of curve numbers may suffice for larger watersheds. HSPF could use updates to the hydrology section and development of an interface to improve both preprocessing and postprocessing capabilities.

Currently, sediment yield in SWAT is computed using the MUSLE. Two options exist for improving the sediment yield module of SWAT. The first option is to include the option of using the USLE or the FosterOnstad USLE in addition to the MUSLE. This will allow the user to select the main erosion energy input. The second option is to include the more physical detachment, transport, and deposition equations used in CREAMS/GLEAMS. This would increase computational time and require the hydrologic modifications mentioned previously.

The field and lake processes for chemical transport in SWAT are adequate, but little consideration is given to channel processes other than deposition. Since the time in channels during transport is small compared with residence time in the field or in lakes, this is only a minor concern for small watersheds. However, for large watersheds or basins, it represents a problem. Applying SWAT to an urban watershed may present an additional problem. SWRRB successfully simulated the effects of urbanization on a watershed, but at this time SWAT has not been validated on an urban watershed. Perhaps an approach similar to HSPF, using different modules to compute loadings from urban areas, could be used. 
If HSPF is selected as the starting point, several upgrades in the hydrologic portion of the model are needed. The hydrology in HSPF is based on the Stanford Watershed Model developed in the early 1960's. Many of the components in use at that time, although sufficient, are outdated. Better methods to compute evapotranspiration need to be included; PenmanMonteith, Hargreaves-Samani, or Priestly-Taylor should be considered. The infiltration section should be upgraded with Green-Ampt methodology. Percolation and groundwater flow need to be addressed better. Application of nonprecipitation (irrigation) events needs to be included in the water balance.

Sediment production simulations are adequate, and temporal changes in cover are addressed in the AGCHEM yield uptake algorithm. The AGCHEM module utilizes monthly factors and plant/harvest dates. Nitrogen fixation has been included as well as volatilization and soluble organics. The effects on groundwater quality should be included. However, the inclusion of a groundwater component could be a major undertaking unless a very simple approach is used. In addition to these items, an interface with a GIS is needed as well as a weather generator to reduce data collection and entry time.

Current research being undertaken by the EPA focuses on the development of a GIS and preprocessor and postprocessor for HSPF. The efforts of the EPA have created a software package known as Better Assessment Science Integrating a Point and Nonpoint Sources (BASINS). Current limitations of the BASINS package are that many of the HSPF algorithms are not available. Furthermore, the database is structured such that is not easily modified for site-specific applications. An advantage of the BASINS program is that several options are available for routing water through stream channels. Other than the HSPF routing methods, QUAL2E and TOXIROUTE are available within the system. Another system developed by the U.S. Army Engineer Waterways Experiment Station (WES) is the Watershed Modeling System (WMS). This state-of-the-art system allows for utilization of available GIS data for delineation of watershed boundaries and assignment of attributes such as land use type, soil type, etc. The WMS offers excellent preprocessing and postprocessing capabilities and the flexibility to build unique watershed databases from user provided data. The WMS also contains several models including HEC1, TR20, CASC2D, and XMODEL. BASINS and WMS are the two major watershed modeling interfaces that can be used to address total maximum daily loads, land use changes, nonpoint sources loadings, etc.

Upon reviewing existing watershed water quality models, it is recommended that the HSPF model be utilized as the building block for the development of a Corps of Engineers modeling capability for predicting watershed runoff water quality as influenced by land use change, development, watershed improvement strategies, and best management practices. The model should be integrated within the existing WMS to facilitate preprocessing and postprocessing while allowing the user maximum flexibility to easily modify databases to meet the demands of site-specific 
applications. Like the BASINS program, WMS is expanding, and it is anticipated that other models will be linked into the system. CE-QUALW2 is listed among these models, and this model will offer an improved reservoir routing simulation option which could be used in conjunction with HSPF. Another advantage of HSPF is that the code is constantly being updated and maintained. Both the EPA and the USGS provide significant financial resources to ensure the code is state of the art. The official version of the code is provided by the EPA. Through incorporation of the HSPF code into the WMS, the Corps of Engineers will have the modeling capability required to determine basin-wide impacts on the water quality of receiving waters. 


\section{References}

Abbott, J. (1978). "Testing of several runoff models on an urban watershed," Technical Paper No. 59, The Hydrologic Engineering Center, U.S. Army Corps of Engineers, Davis, CA.

Alley, W. M., and Smith, P. E. (1982a). "Distributed routing rainfallrunoff model-Version II; Computer program documentation user's manual," Open-File Report 82-344, Water Resources Division, U.S. Geological Survey, Department of the Interior.

. (1982b). "Multi-event urban runoff quality model; Computer program documentation user's manual," Open-File Report 82-764, Water Resources Division, U.S. Geological Survey, Department of the Interior.

Arnold, J. G., and Williams, J. R. (1994). "SWRRB; A watershed scale model for soil and water resource management," Grassland Soil and Water Research Laboratory, U.S. Department of AgricultureAgriculture Research Service, Temple, TX.

Arnold, J. G., Williams, J. R., Srinivasan, R., and King, K. W. (1995). "SWAT: Soil and water assessment tool," Grassland, Soil and Water Research Laboratory, U.S. Department of Agriculture-Agriculture Research Service, Temple, TX.

Ascough, J. C., II, Baffaut, C., Nearing, M. A., and Flanagan, D. C. (1995). "Watershed model channel hydrology and erosion processes," USDA-Water Erosion Prediction Project Hillslope Profile and Watershed Model Documentation, D. C. Flanagan and M. A. Nearing, eds., NSERL Report No. 10, U.S. Department of Agriculture-Agriculture Research Service, National Soil Erosion Research Laboratory, West Lafayette, IN.

Bicknell, B. R., Imhoff, J. C., Kittle, J. L., Jr., Donigian, A. S., Jr., and Johanson, R. C. (1993). "Hydrological Simulation Program-Fortran user's manual for Release 10," EPA/600/R-93/174, U.S. Environmental Protection Agency, Athens, GA. 
Center for Exposure Assessment Modeling. (1994). "SWMM, storm water management model version 4.30," U.S. Environmental Protection Agency, Office of Research and Development, Athens, GA.

Donigian, A. S., Jr., and Huber, W. C. (1990). "Modeling of nonpoint source water quality in urban and non-urban areas," Aqua Terra Consultants, Moutainview, CA, for Environmental Research Laboratory, Office of Research and Development, U.S. Environmental Protection Agency.

Dumesnil, D., ed. (1993). "EPIC user's guide," Grassland, Soil and Water Research Laboratory, U.S. Department of Agriculture-Agriculture Research Service, Temple, TX.

Flanagan, D. C., Ascough, J. C., II, Nicks, A. D., Nearing, M. A., and Laflen, J. M. (1995). "Overview of the WEPP erosion prediction model," USDA-Water Erosion Prediction Project Hillslope Profile and Watershed Model Documentation, D. C. Flanagan and M. A. Nearing, eds., NSERL Report No. 10, U.S. Department of AgricultureAgriculture Research Service, National Soil Erosion Research Laboratory, West Lafayette, IN.

Foster, G. R., Flanagan, D. C., Nearing, M. A., Lane, L. J., Risse, L. M., and Finkner, S. C. (1995). "Hillslope erosion component," USDAWater Erosion Prediction Project Hillslope Profile and Watershed Model Documentation, D. C. Flanagan and M. A. Nearing, eds., NSERL Report No. 10, U.S. Department of Agriculture-Agriculture Research Service, National Soil Erosion Research Laboratory, West Lafayette, IN.

Foster, G. R., Lane, L. J., Nowlen, J. D., Laflen, J. M., and Young, R. A. (1980). "A model to estimate sediment from field-sized areas," CREAMS A Field Scale Model for Chemicals, Runoff, and Erosion from Agricultural Management Systems, W. G. Knise1, ed., Conservation Research Report No. 26, U.S. Department of Agriculture.

Hydrologic Engineering Center. (1977). "STORM storage, treatment, overflow runoff model user's manual," CPD-7, U.S. Army Corps of Engineers, Davis, CA.

Knisel, W. G., ed. (1993). "GLEAMS: Groundwater loading effects of agricultural management systems," U.S. Department of AgricultureAgriculture Research Service, Southeast Watershed Research Laboratory, Tifton, GA.

Mullins, J. A., Carsel, R. F., Scarbrough, J. E., and Ivery, A. M. (1996). "PRZM-2, A model for predicting pesticide fate in the crop root and unsaturated soil zone: User's manual for Release 2.0," Environmental Research Laboratory, U.S. Environmental Protection Agency, Athens, GA. 
Nicks, A. D., Lane, L. J., and Gander, G. A. (1995). "Weather generator," USDA-Water Erosion Prediction Project Hillslope Profile and Watershed Model Documentation, D. C. Flanagan and M. A. Nearing, eds., NSERL Report No. 10, U.S. Department of Agriculture-Agriculture Research Service, National Soil Erosion Research Laboratory, West Lafayette, IN.

Savabi, M. R., Young, R. A., Benoit, G. R., Witte, J. M., and Flanagan, D. C. (1995). "Winter hydrology," USDA-Water Erosion Prediction Project Hillslope Profile and Watershed Model Documentation, D. C. Flanagan and M. A. Nearing, eds., NSERL Report No. 10, U.S. Department of Agriculture-Agriculture Research Service, National Soil Erosion Research Laboratory, West Lafayette, IN.

Sharpley, A. N., and Williams, J. R., eds. (1990). "EPIC-Erosion/ productivity impact calculator; 1 . Model documentation," Technical Bulletin No. 1768, U.S. Department of Agriculture.

Smith, R. E., and Williams, J. R. (1980). "Simulation of surface hydrology," CREAMS A Field Scale Model for Chemicals, Runoff, and Erosion from Agricultural Management Systems, W. G. Knisel, ed., Conservation Research Report No. 26, U.S. Department of Agriculture.

Stone, J. J., Lane, L. J., Shirley, E. D., and Hernandez, M. (1995). "Hillslope surface hydrology," USDA-Water Erosion Prediction Project Hillslope Profile and Watershed Model Documentation, D. C. Flanagan and M. A. Nearing, eds., NSERL Report No. 10, U.S. Department of Agriculture-Agriculture Research Service, National Soil Erosion Research Laboratory, West Lafayette, IN.

Viessman, W., Jr., Knapp, J. W., Lewis, G. L., and Harbaugh, T. E. (1977). Introduction to Hydrology. Harper \& Row, New York.

Williams, J. R. (1994). "The EPIC model," Grassland, Soil and Water Research Laboratory, U.S. Department of Agriculture-Agriculture Research Service, Temple, TX.

Wurbs, R. A. (1995). Water Management Models; A Guide to Software. Prentice-Hall, Inc., Englewood Cliffs, NJ.

Young, R. A., Onstad, C. A., Bosch, D. D., and Anderson, W. P. (1994). "Agricultural Non-Point Source Pollution Model, Version 4.03, AGNPS user's guide," North Central Soil Conservation Research Laboratory, U.S. Department of Agriculture-Agriculture Research Service, Morris, MN. 


\section{REPORT DOCUMENTATION PAGE}

Public reporting burden for this collection of information is estimated to average 1 hour per response, including the time for reviewing instructions, searching existing data sources, gathering and maintaining

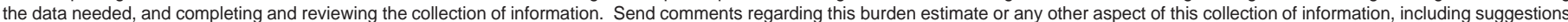

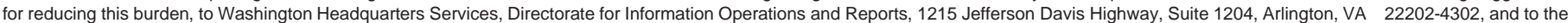
Office of Management and Budget, Paperwork Reduction Project (0704-0188), Washington, DC 20503.
1. AGENCY USE ONLY (Leave blank)
2. REPORT DATE
3. REPORT TYPE AND DATES COVERED
January 1999
Final report

\section{TITLE AND SUBTITLE}

Review of Watershed Water Quality Models

5. FUNDING NUMBERS

6. AUTHOR(S)

Patrick W. Deliman, Roger H. Glick, Carlos E. Ruiz

\section{PERFORMING ORGANIZATION NAME(S) AND ADDRESS(ES)}

U.S. Army Engineer Waterways Experiment Station

3909 Halls Ferry Road, Vicksburg, MS 39180-6199
8. PERFORMING ORGANIZATION REPORT NUMBER

Technical Report W-99-1
9. SPONSORING/MONITORING AGENCY NAME(S) AND ADDRESS(ES)

U.S. Army Corps of Engineers

Washington, D.C. 20310
10. SPONSORING/MONITORING AGENCY REPORT NUMBER

\section{SUPPLEMENTARY NOTES}

Available from National Technical Information Service, 5285 Port Royal Road, Springfield, VA 22161.

12a. DISTRIBUTION/AVAILABILITY STATEMENT

Approved for public release; distribution is unlimited. 12b. DISTRIBUTION CODE

13. ABSTRACT (Maximum 200 words)

This review was conducted to determine the current state of the art in watershed water quality modeling. Several available watershed water quality models were reviewed and rated with regard to their potential in being utilized as the building block for the development of a Corps of Engineers watershed water quality model. Watershed water quality models are currently being implemented for predicting watershed runoff water quality as influenced by land use change, development, watershed improvement strategies, best management practices, and in the determination of total daily maximum loads. The model selected as a building block for the Corps of Engineers model will be implemented into the U.S. Army Engineer Waterways Experiment Station's Watershed Modeling System (WMS). The WMS can be used currently in the application of watershed models for both preprocessing and postprocessing. Current models contained in the WMS do not have water quality capabilities. Thus, the implementation of the selected watershed water quality model into the system will extend the capabilities of the system to include watershed water quality modeling.

\section{SUBJECT TERMS}

Water quality

Watershed Modeling System

Watershed water quality model
15. NUMBER OF PAGES

31

16. PRICE CODE

\section{SECURITY CLASSIFICATION OF REPORT \\ UNCLASSIFIED \\ 18. SECURITY CLASSIFICATION OF THIS PAGE UNCLASSIFIED}

Standard Form 298 (Rev. 2-89) Prescribed by ANSI Std. Z39-18 298-102 
Destroy this report when no longer needed. Do not return it to the originator. 